\title{
EFFECT OF SOME INTERCROPPING SYSTEMS AND POTASSIUM FERTILIZATION RATE FOR MAIZE WITH COWPEA CROPS ON THE POPULATION DENSITY OF CERTAIN PESTS AND THEIR NATURAL ENEMIES IN SHRAKIA GOVERNORATE, EGYPT. Abd-Elsamed, A.A.; M.S. Hashem and A.A.A. Salah \\ Plant Protection Res. Institute, Agric. Res. Center, Dokki , Giza, Egypt.
}

\begin{abstract}
This study was conducted to evaluate the effect of intercropping and potassium fertilization for maize with cowpea plants on the population density levels of some piercing -sucking insects at Diarb Negm distract in Sharkia Governorate during 2009 and 2010 seasons. The obtained results showed that intercropping system (3:3) maize with cowpea decreased Rhopalosiphum maidis (Fitch), Rhopalosiphum padi(L .) , Aphis gossypii (Glover), Empoasca decedens (Paoli), Empoasca decipiens(Paoli) , Cicadulina chinai (Ghauri) and whitefly Bemisia tabaci (Genn.). Whereas, increased average numbers of planthopper Sogatella vibix (Haupt) and Sogatella furcifera (Horv.) in both seasons. The results indicate that increased of yield in the solid system but insignificantly with intercropping system (3:3). Data presented clearly that rate of $100 \mathrm{~kg}$ of potassium fertilization / fed. gave increased of yield maize with cowpea plants and decreased infestation of sap-sucking insects in both seasons. Lysiphlebus fabarum (Marshall) was the singe primary parasitoid species emerged from Aphis craccivora (Koch.) mummies Also, Diaeretiella rapae (M' Intosh) was the primary parasitoid emerged from $R$. maidis mummies and Praon $\mathrm{sp}$. was the primary parasitoid emerged from $R$. padi mummies. The mean percentage of parasitoid were $5.52 \pm 2.02$ and $4.33 \pm 1.58$ in (L. fabarum), $1.21 \pm 0.43$ and $1.71 \pm 0.46(D$. rapae) and it were $1.38 \pm 0.53$ and $1.11 \pm 0.35$ (Praon sp.) in both seasons respectively. Five predators were associated with these insects on cowpea crop. These predators were Coccinella undecimpunctata (L.), Cydonia vicina isis, Cy. vicina nilotica, Metasyrphus corolla (F.) and Chrysoperla carnae (Steph). Meanwhile three predators were associated with these insects on maize crop. These predators were $C$. undecimpunctata, M. corolla (F.) and C. carnae.
\end{abstract}

Keywords: Aphid, leafhoppers, Aphid parasitoids, Predators.

\section{INTRODUCTION}

Intercropping is considered one of the safe and effective control agents which is successfully used in IPM program of cotton pests (Rao and Reedy, 1999). Companion cropping, which increases crop diversity, modifies the insects habitat interferes with the insects identification of, and responses to, its host plant (Tahvanainen and Root, 1972). Modifications that lead to the reduction of population of a pest have been referred to as cultural control (Root, 1973). Many farmers in the tropics practice companion cropping involving a few to several crops (Okigbo and Greenland, 1976). Cowpea is mostly intercropping with maize, soybean, millet and cassava. Studies on the effect of companion cropping on insect pests have been conducted in systems involving cowpea - maize, cowpea - sorghum and cowpea Cassava, association (Singh and Rachie, 1985). The population of Empoasca 
dolichi, Sericothrips occipitalis and callosobruchus maculates as well as flower thrips were reduced in cowpea - maize intercropping (Perfect et al., 1978; Matteson, 1982; Ezuech and Taylor, $1984 . \quad$ Rosseto et al., 1997) found that the fertilization (NPK) increased the numbers of aphid on cotton while aphid numbers decreased in absence of fertilizers and phosphorus. Application of potassium increased of population of $T$. urticae, which was reduced in the presence of hen manure. Watson et al., (1994) studied the effect of three nitrogen fertilizer levels on the development of sweet potato whitefly (Bemisia tabaci) population infesting cotton plants and found that the nitrogen level had no effect on its development. This study was conducted to evaluate the effect of different intercropping cowpea with maize on the infestation of pests and investigate the effect of potassium fertilization on the infestation levels of some pests.

\section{MATERIALS AND METHODS}

Field experiment was carried out at Dierb- Nigm distract in Sharkia Governorate, Egypt during the two successive growing seasons 2009 and 2010.

\section{1- Intercropping systems.}

To investigate the effect of certain agricultural practices on some insect pests and their natural enemies associated with maize and cowpea plants under solid and intercropping system, the experimental design was split plot in all growing season, of maize and cowpea plants. An area of about half fed, was divided into three replicates were used for each treatment. Each subplot consisted of 12 ridges (6 meters length and $60 \mathrm{~cm}$ width), in case of solid cultivation, one side of the ridges was planted with maize at $35 \mathrm{~cm}$ spaces, while one side of ridges were planted with cowpea at $15 \mathrm{~cm}$ spaces, in case of first intercropping system (1:1), the second (3:3) included three ridges of maize: three ridges of cowpea plants respectively. In intercropping maize of 2031 variety (High Tic Company) and cowpea, cream 7 variety were cultivated on the $2^{\text {nd }}$ week of May in both 2009 and 2010 season.

I-Sampling technique

\section{a) Maize plants (Zea mays L.)}

Aphid (Aphididae: Homopetra)

Weekly, samples consisting of ten leaves and five tissues from different intercropping and solid were taken at randomly from different levels of plants when the aphid found on the plants until harvest. These samples were kept in tightly closed paper bags and then transferred to laboratory for examination on the same day with the aid of a stereomicroscope.

\section{Leafhopper and planthopper (Cicadellidae: Auchenorrhynca, Homoptera).-}

Each sample consisted of 100 double strokes by sweep net was taken randomly from both diagonals of the field. The samples were taken weekly to surveyed, counted leafhopper and planthopper insects. 


\section{B): Cowpea plants (Vigna unquiculata L.)}

\section{Aphid and whitefly (Aphididae Aleyrodidae :Homoptera)}

Weekly, samples consisting of 25 leaves from different intercropping and solid were taken randomly from plants after four weeks from sowing date until harvest. These samples were kept in tightly closed paper bags and then transferred to laboratory from examination of the same day with the aid of a stereomicroscope. The number of aphids as well whitefly and their predators and parasitoids were counted on two surfaces.

2-Leafhopper (Cicadellidae : Homoptera):-

Each sample consisted of 100 double strokes by sweeping net was taken random from both diagonals.

\section{II) Effect of fertilization}

The experimental was divided four treatments, $25,50,100 \mathrm{~kg}$ of potassium sulphate $\left(48 \% \mathrm{k}_{2} \mathrm{O}\right)$ fertilization / fed. and control (without potassium fertilization). Normal agricultural practices were applied without pesticides treatments. Samples of leaves were taken weekly as previously mentioned in intercropping. Costat software program (1990) was used for data analysis of insect species.

III) Natural enemies:

\section{Survey and estimate of parasitism in the field:}

Field studies were carried out during 2009 and 2010 seasons on cowpea and maize. Weekly randomly samples of aphids infested twenty five leave from cowpea crop and ten leaves and five tissues from maize plants. Samples were transported to the laboratory in tight closed plastic bags. All aphid individuals found on leaves/ sample were counted. Aphid were supplied by fresh host leaves and supplied by fresh host leaves and kept in Petri dishes (50 aphids/Petri dish) until formation of mummies. The emerged parasitoids were mounted and identified. Rates of parasitism were estimated according to Farrell and Stufkens (1990).

$$
\text { Percentage of parasitism }=\frac{A+B}{A+B+C} \times 100
$$

$A=$ Number of mummified aphids counted at the date of inspection

$B=$ number of mummified host appeared during the laboratory rearing.

$\mathrm{C}=$ No. of unparasitized aphids.

Samples were taken weekly from solid plot and calculated monthly. Also associated predators with insects were surveyed and counted on cowpea (25 leaves) and maize (ten leaves and five tissues)

\section{RESULTS AND DISCUSSION}

\section{1-Effect of intercropping}

a) Maize plants:-

1- Aphid species:-

Data in Table (1) showed that the maize plants intercropped with cowpea were infested by three aphid species $R$. maidis, $R$. padi, and $A$. gossypii the obtained results revealed that solid increased the population 
density of $R$. maidis, $R$. padi and $A$. gossypii compared with intercropping. The solid was influenced, the occurrence of aphid species highly significantly in compared with intercropping maize. These results agree with those of Hegab et al (1987) and Abd- Elsamed (2006) who found that aphid species $R$. maidis , R. padi and A. gossypii in maize field

\section{2-Leafhopper and planthoppers insects:-}

The presented data in Table (1) showed that three leafhopper species $E$. decedens, E. decipiens and C. chinae were recorded. The solid was influenced, the occurrence of leafhoppers highly significantly in compared with intercropping maize plants. The population density of $E$. decedens was 63.71, 43.82, 37.57and 46.15, 38.08 and 38.61 individuals / sample in both seasons respectively. On the other hand, the population density of E. decipiens were $50.79,40.87$ and 38.46 individuals per sample in the first season and $53.14,48.46$ and 45.68 individuals / sample in the second season, mean while population density of $C$. chinae were 43.27, $35.58,33.66$ and $36.35,25.21,23.79$ individuals / sample in both seasons respectively. The average number of $S$. vibix were $36.11,37.55$ and 43.82 individuals / sample in 2009 season and 30.32, 34.96 and 40.74 individuals / sample in 2010 season, while mean numbers of $S$. furcifera were28.52, 30.0, 36.57 and $31.45,32.22$ and 39.66 individuals / sample in both seasons at different intercropping system solid, 1:1 and 3:3 (maize: cowpea), respectively. These findings agree with Hegab (1993) and Hegab - Ola (1997 \& 2001)

\section{B) Cowpea plants:-}

\section{Aphid:-}

Data in Table (2) showed that the cowpea plants intercropping with maize were infested by two aphid species $A$. craccivora and $A$. gossypii. The average numbers of $A$ craccivora were $370.14,361.86,236.68$ individuals / sample in the first season and 214.63, 198.44, 185.81 individuals /sample in the second season respectively. On the other hand the population density of A. gossypii were 46.48, 37.03, 27.83 and 31.51, 29.76, 22.20 /sample in both seasons at different intercropping system solid, 1:1 and 3:3 (cowpea : maize) respectively. Similar results were obtained by El - Gindy (2002) and AbdElsamed (2006) who found that aphid species A. craccivora and A. gossypii in leguminous plant species, cowpea, bean, broad bean and pea.

\section{Leafhopper:}

Data in Table (2) cleared that three leafhopper species E. decedens, $E$. decipiens and $C$. chinae were found. The intercropping was influenced, the occurrence of leafhoppers, E. decedens and E. decipiens highly significantly and insignificantly with $C$. chinae compared with solid cowpea plants. In both seasons respectively (Table 2).

The present results agree with those obtained by Ammar and Farrag (1976), Mowafy (1988), El- Sayed (1993) and El- Gindy (2002) who surveyed the aforementioned homopterous insects on leguminous plants. 
J. Plant Prot. and Path., Mansoura Univ., Vol. 2 (2), February, 2011

$1-2$ 
Whitefly:-

Data in Table (2) cleared that the cowpea intercropping system with maize decreased the population density of whitefly compared with solid the means population density of adult $B$. tabaci were 72.36, 50.60, 34.17 and $35.34,31.8,28.72 /$ sample. while immature stage were $110.85,99.0,80.0$ and $90.87,81.17,73.43 /$ sample in both seasons at different intercropping system solid, 1:1 and 3:3 (cowpea: maize) respectively. The present result agrees with those obtained by Hammad (1978), El- Gindy (2002) and Hashem (2005).

Mean yield (Kg/plot).

Table (1 and 2) showed that yield maize plants were affected significant by intercropping. Solid system yielded the highest mean of (39.45) and $(49.22) \mathrm{Kg} /$ plot in two seasons, respectively. While intercropping (3:3) system (34.21) and (42.79) Kg/plot insignificant with solid system in 2009 and 2010 seasons respectively. The same phenomenon took place with cowpea plant, yield solid system (9.08) and (10.20) $\mathrm{Kg}$ /plot insignificant with (3:3) system (8.05) and (9.78) in the first and second season, respectively.

As previously mention intercropping system did play an important role in mean yield of maize and cowpea plants.

\section{2) Effect of fertilization:-}

Three level 25, 50, $100 \mathrm{~kg} / \mathrm{fed}$. of potassium were applied as soil fertilization and control (without potassium fertilization) to study their effects on the population density of some injurious pests attacking maize and cowpea plants during two successive growing seasons of 2009 and 2010. The obtained results could be discussed as follows:

\section{a) Pests attacking maize intercropping with cowpea plants:}

Aphid: Data in Table (3) showed that the effect of potassium fertilizer on the infestation degree of maize plants with maize aphids $R$. maidis, $R$. padi and A. gossypii) were statistically highly significant in both seasons. The highest averages numbers of $1272.28,1169.13$ and $782.76,708.25$ insects $(R$. maidis) leaf occurred on leaves of maize plants fertilized by F4 (without potassium fertilization) and F3 (25kg of potassium fertilization / fed.) during 2009 and 2010 seasons, respectively. Whereas, the lowest population density of this pest ( $R$. maidis) was recorded in $\mathrm{F} 1$ (100kg potassium fertilization / fed.) in both seasons (955.99 and 596.26 insects) respectively. While the highest averages numbers of $R$. padi were 597.87, 543.29 and $494.97,456.90$ insects/sample occurred on leaves of maize plants fertilized by F4(without potassium fertilization) and F3 (25 kg of potassium fertilization / fed.) during 2009 and 2010 seasons respectively. On the other hand the highest averages numbers of $A$. gossypii were 83.57, 74.4 and 74.93, 68.10 insect/sample occurred on leaves of maize plants fertilized by F4 and F3 during two seasons, respectively.

Leafhopper and Planthopper:-

Data in Table (3) cleared the effect of potassium fertilizer on the infestation degree of maize plants with three leafhopper and two planthopper were statistically highly significant in both seasons. The highest average numbers of leafhopper, E. decedens, E. decipiens and C. chinae were 45.14, 41.71\& 48.75, 44.27 and 42.79, 39.98 insects/sample occurred on leaves 
fertilized by F4 and F3 in the first season respectively. But in the second seasons its were 49.12, 44.35\& 54.32, 51.51 and 34.26, 31.46 insects/sample occurred on leaves fertilized by F4 and F3 respectively. On the other hand the highest average numbers of Planthopper, $S$. vibix and $S$. furcifera were 43.81, $40.96 \& 40.89,37.24$ and $36.96,33.52 \& 41.46,35.54$ insect/ sample occurred on leaves fertilized by F4 (without potassium fertilization) and F3 (25kg of potassium fertilization / fed.) during 2009 and 2010 seasons, respectively. On the other hand, intercropping cowpea after 12 weeks from maize planting, significantly reduced insect damage thus determining the best system for intercropping cowpea with maize (Ezuech and Taylor, 1984)

\section{B) Pests attacking cowpea intercropping on maize plants}

Aphid insects:

Data Table (4) revealed that effect of potassium fertilizer on infestation degree of cowpea plant with two cowpea aphid $A$. craccivora and A. gossypii were statistically highly significant in both seasons. The highest averages numbers of $A$. craccivora and $A$. gossypii 363.50, 346.39\& 226.15, 204.96 and 46.52, $39.66 \& 34.89,29.76$ insects /sample occurred on leaves of cowpea plants fertilized by F4 (without potassium fertilization ) and F3 (25kg potassium fertilization /fed.) during two season 2009 and 2010, respectively.

\section{Leafhopper:}

Data Table (4) indicated that the effect of potassium fertilizer on the infestation degree of cowpea plants with three leafhopper $E$. decedens, $E$. decipiens and $C$. chinae were statistically highly significant in both seasons. The highest averages number of three leafhopper were 14.71, 12.97\& 25.92, 19.92 and 6.62, 5.94 insects/sample occurred on fertilized by F4 and F3 in the first season. Meanwhile in the second season it were 12.79, 11.32\& $18.46,15.64$ and $7.21,6.53$ insects/sample occurred on fertilized by F4 and F3 respectively.

3) Whitefly:

Data in Table (4) cleared the effect of potassium fertilization on the infestation degree of cowpea was statistically highly significantly in both seasons. The highest averages numbers were $66.20,57.68$ and $36.93,34.14$ insects /sample occurred on fertilized by F4 (without potassium fertilization) and F3 (25kg potassium fertilization / fed.) during the two seasons of study respectively.

The present results revealed that cowpea plants were infested with A. gossypii and A. craccivora these pests were recorded on cowpea plants by Mali and Kulthe (1980) and Hassan (2009). However, intercropping of cotton with cowpea significantly influenced the spread of $A$. gossypii, E. dicipiens and B. tabaci. Suggesting that the presence of cowpea plant with cotton could result in a reduced population build up of these insect (Omar et al.(1991) and Omar et al.(1994)) However, the high rates of potassium reduced the population density of these pests on cereal, legumes and maize plants. These results are in same line of Hegab (2001), El- Gindy (2006) and El - Gindy et al.(2009). 
Abd-Elsamed, A.A. et al.

$3-4$

160 
They mentioned that as the increase of potassium fertilization the population density of many homopterous pests decreased. Similar conclusion was obtain by the same authors, they found that potassium fertilization increased the thickness of epidermal leaves and suppressed the infestation of several piercing and piercing sucking insect pests on cereal, legumes and maize plants

Mean yield (Kg/plot).

As clearly shown from the results in Table ( 3 and 4$)$, the yield of maize plants treated with the different tested treatments was highly significant as flounced by fertilization treatments. The highest yield of (46.36 and 58.03) $\mathrm{Kg} /$ plot was recorded with $\mathrm{F} 1$ (100 $\mathrm{kg}$ potassium fertilization /fed.) whereas, the lowest yield of (16.56 and 20.49) Kg/plot was recorded with F4 (control) in the first and second seasons, respectively.

The same phenomenon took place with cowpea plants Table (4) data show that mean yield in both seasons increased with increasing the rat of the used fertilization the highest yield of (10.70 and 13.02) Kg/plot was recorded with $\mathrm{F} 1$ whereas, the lowest yield of (5.96 and 6.67$) \mathrm{Kg} /$ plot was recorded with F4 (control).

III) Natural enemies:

III.1- Cowpea:

III.1.A. Aphid parasitoids

Weekly counts of aphid (A. craccivora) on cowpea leaves during 2009 and 2010 seasons are given in (Table 5).

Table (5): Monthly mean percentage of parasitism A. craccivora by Lysiphlebus fabarum on cowpea plants during the two successive seasons $2009-2010$.

\begin{tabular}{|c|c|c|c|c|c|c|c|}
\hline \multirow[b]{2}{*}{ seasons } & \multirow{2}{*}{$\begin{array}{c}\text { Sampling } \\
\text { dates }\end{array}$} & \multirow{2}{*}{$\begin{array}{c}\text { No. of } \\
\text { examined } \\
\text { aphid }\end{array}$} & \multicolumn{3}{|c|}{ No. of parasitized } & \multirow[b]{2}{*}{ C. } & \multirow[b]{2}{*}{ Parasitism\% } \\
\hline & & & A & B & total & & \\
\hline \multirow{3}{*}{2009} & July & 850 & 3 & 7 & 10 & 840 & 1.18 \\
\hline & August & 626 & 16 & 12 & 28 & 598 & 4.47 \\
\hline & Sep. & 660 & 28 & 44 & 72 & 588 & 10.91 \\
\hline \multicolumn{2}{|r|}{ Mean } & $712 \pm 49.27$ & 15.66 & 21 & 36.66 & 675.34 & $5.52 \pm 2.02$ \\
\hline \multirow{4}{*}{2010} & June & 993 & 0 & 0 & 0 & 993 & 0 \\
\hline & July & 602 & 5 & 8 & 13 & 589 & 2.16 \\
\hline & August & 450 & 10 & 15 & 25 & 425 & 5.56 \\
\hline & Sep. & 593 & 24 & 33 & 57 & 536 & 9.61 \\
\hline & Mean & $659.5 \pm 87.92$ & 9.75 & 14 & 2375 & 635.75 & $4.33 \pm 1.58$ \\
\hline
\end{tabular}

During the first season (2009), the infestation started during the $4^{\text {th }}$ of July with (1038 individuals / sample) mean while, the infestation started to appear during the $1^{\text {st }}$ week of July with (993 individuals/ 25 leaves) in 2010 season. Lysiphlebus fabarum was the single primary parasitoid species emerged from $A$. craccivora mummies. Percentage of parasitism ranged between 2.35 - 12.08 and 2.27 - $10.14 \%$ in 2009 and 2010 seasons respectively. The highest percentage of parasitism was 12.08 and $10.14 \%$ in the both seasons respectively. Also the mean percentage of parasitism were 
$5.52 \pm 2.02$ and $4.33 \pm 1.58$ in the two seasons respectively. Selim et al. (1987) and Abdel- Samad (1996) recorded L. fabarum as a parasitoid on $A$. craccivora in Egypt. Ragab(1996) and Abdel- Samad (1996) recorded $T$. angelicae (Hal.) as parasitoid of $A$. craccivora. This latter parasitoid $T$. angelicae was not recorded on the same aphid species during the present study. The present results agree with those of Abdel - Samad (1996) and Ragab et al. (2002) who mentioned that $D$. rapae, L. fabarum and Ephedrus $s p$. as a parasitoids of $A$. craccivora. However Abdel- Samad (1996) in Egypt reported that the rate of parasitism varied between 15.4 and 22.0 in March on the some aphid species. Also Ragab et al. (2002) in Egypt showed that the highest total percentage of parasitism was $15.14 \%$ in February in the first season (1998), meanwhile, it was $17.40 \%$ in January in the second season (1999).

\section{III.1.B. Predators}

Results in Table (8) showed that the predator species found on cowpea plants 2009 and 2010 seasons, respectively. Six beneficial insects, these species are belonging to orders: Coleopteran, Diptera , Neuroptera and Hymenoptera. The total numbers and ratio of these species were $C$. undecimpunctata (78 individual $=16.88 \%$ and 92 individuals $=23.96$ ), $C y$. vicinia isis (33 individuals $=7.14 \%$ and 22 individuals $=5.73 \%$ ), Cy. vicinia nilotica (19 individuals $=4.11 \%$ and 14 individuals $=3.65 \%), M$. corollae $(15$ individuals $=3.25 \%$ and 11 individuals $=2.86 \%)$, C. carnea $(17$ individuals $=$ $3.68 \%$ and 12 individuals $=3.13 \%)$ and $(300$ individuals $=64.94 \%$ and 233 individuals $=60.68 \%$ ) in both seasons respectively . However, Mohamed (1996) mentioned that beneficial insects in sweet pea, the dominant beneficial species were, $C$. undecimpuntata, Cy. Vicina isis, S. syriacus, Cy. Vicinia nilotica and $M$. corollae.

\section{III.2. Maize:-}

III.2.A. Aphid parasitoids:

Two aphid species, $R$. maidis and $R$. padi were surveyed on maize plants during 2009 and 2010 seasons. The weekly counts of the two aphid species were given in (Table 6\&7). During the first season(2009), the infestation started to appear from the beginning of the $1^{\text {st }}$ week of July with (601 individuals/sample) $R$. maidis and (280 individauls /sample ) $R$. padi, while it appeared during the $4^{\text {th }}$ of June with (592 individual/ sample) $R$. maidis and 256 individual/ sample) $R$. padi, in 2010 season. $D$. rapae was the primary parasitoid emerged from $R$. maidis mummies and Praon sp. was the primary parasitoid emerged from $R$. padi mummies. Percentage of parasitism ranged between 0.75 to $3.00 \%$ and 0.84 to $3.49 \%$ for $D$. rapae on $R$. midis in both seasons 2009 and 2010. Mean while the percentage parasitism of Praon sp. on $R$. padi ranged between 0.80 to $3.45 \%$ and 0.79 to $2.44 \%$ in both seasons respectively. The mean percentage of parasitism were $1.21 \pm 0.47$ and $1.71 \pm 0.46(D$. rapae $)$ and it were $1.38 \pm 0.53$ and 1.11 \pm 0.35 (Praon sp.) in both seasons, respectively. However, AL Hag et al, (1996) recorded that $D$. rapae as an important parasitoid of $R$. maidis on wheat and barley fields in Saudi Arabia. Meanwhile, Giustina et al.,(1982) concluded that the main parasitoids of $R$. padi on maize plant were Aphidius $s p$. Praon sp., and Aphelius sp. On the other hand, $D$. rapae is an important 
primary parasitoid of a wide range of aphid species in the world and Egypt, Brevicoryne brassicae, Myzus persicae, Diuraphis noxia, A. gossypii, A. craccivora, $R$. padi, $R$. maidis and A. nerii (Saleh 2004 and Vazet et al.,2004).

Table (6): Monthly mean percentage of parasitism $R$. maidis by $D$. rapae on maize plants during the two successive seasons 2009 2010.

\begin{tabular}{|c|c|c|c|c|c|c|c|}
\hline \multirow[b]{2}{*}{ seasons } & \multirow{2}{*}{$\begin{array}{c}\text { Sampling } \\
\text { dates }\end{array}$} & \multirow{2}{*}{$\begin{array}{l}\text { No. of } \\
\text { examined } \\
\text { aphid }\end{array}$} & \multicolumn{3}{|c|}{ No. of parasitized } & \multirow[b]{2}{*}{ C. } & \multirow[b]{2}{*}{ Parasitism\% } \\
\hline & & & A & B & total & & \\
\hline \multirow{3}{*}{2009} & July & 558 & 0 & 0 & 0 & 558 & 0 \\
\hline & August & 375 & 2 & 3 & 5 & 370 & 1.33 \\
\hline & Sep. & 391 & 3 & 6 & 9 & 382 & 2.30 \\
\hline \multicolumn{2}{|c|}{ Mean } & $441.33 \pm 41.37$ & 1.66 & 3 & 4.66 & 436.67 & $1.21 \pm 0.47$ \\
\hline \multirow{4}{*}{2010} & June & 521 & 0 & 0 & 0 & 521 & 0 \\
\hline & July & 482 & 3 & 5 & 8 & 474 & 1.66 \\
\hline & August & 498 & 5 & 8 & 13 & 485 & 2.61 \\
\hline & Sep. & 429 & 4 & 7 & 11 & 418 & 2.56 \\
\hline \multicolumn{2}{|c|}{ Mean } & $482.5 \pm 14.75$ & 3 & 5 & 8 & 474.5 & $1.71 \pm 0.46$ \\
\hline
\end{tabular}

Table (7): Monthly mean percentage of parasitism R. padi by Praon sp. on maize plants during the two successive seasons 2009 2010.

\begin{tabular}{|c|c|c|c|c|c|c|c|}
\hline \multirow[b]{2}{*}{ seasons } & \multirow{2}{*}{$\begin{array}{c}\text { Sampling } \\
\text { dates }\end{array}$} & \multirow{2}{*}{$\begin{array}{l}\text { No. of } \\
\text { examined } \\
\text { aphid }\end{array}$} & \multicolumn{3}{|c|}{ No. of parasitized } & \multirow{2}{*}{ C. } & \multirow[b]{2}{*}{ Parasitism\% } \\
\hline & & & A & B & total & & \\
\hline \multirow{3}{*}{2009} & July & 274 & 0 & 0 & 0 & 274 & 0 \\
\hline & August & 257 & 1 & 3 & 4 & 253 & 1.56 \\
\hline & Sep. & 231 & 2 & 4 & 6 & 225 & 2.59 \\
\hline \multicolumn{2}{|c|}{ Mean } & $254 \pm 9.67$ & 1 & 2.33 & 3.33 & 250.66 & $1.38 \pm 0.53$ \\
\hline \multirow{4}{*}{2010} & June & 252 & 0 & 0 & 0 & 252 & 0 \\
\hline & July & 263 & 0 & 2 & 2 & 261 & 0.76 \\
\hline & August & 283 & 2 & 4 & 6 & 277 & 2.12 \\
\hline & Sep. & 255 & 2 & 2 & 4 & 251 & 1.57 \\
\hline \multicolumn{2}{|c|}{ Mean } & $263.25 \pm 5.27$ & 1 & 2.0 & 3 & 260.25 & $1.11 \pm 0.35$ \\
\hline
\end{tabular}

\section{III.2.B. Predators:}

Date in Table (9) illustrated the predator species on maize plants 2009 and 2010 seasons, these species were belonging orders Coleoptera, Diptera, Neuroptera and Hymenoptera. The total numbers and ratio of these species were C. undecimpunctata (15 individuals $=12.82 \%$ and 18 individuals $=12.08 \%), M$. corollae (13 individuals $=11.11 \%$ and 17 individuals $=11.41 \%), C$. carnea $(15$ individuals $=12.82 \%$ and 19 individuals $=12.75 \%$ ), True spiders (19 individuals $=16.24 \%$ and 24 individuals $=$ $16.11 \%$ ), D. rapae (35 individuals $=29.92 \%$ and 55 individuals $=36.91 \%$ ) and Praon sp. (20 individuals $=17.09 \%$ and 16 individuals $=10.74 \%$ ) in two season respectively. However, Darwish and ali (1991) reported that predators comprised about $88 \%$ of the total natural enemies recorded in maize fields in 
upper Egypt. On the other hand Shoeb et al.,(2008) mentioned that predators migrated from Egyptian clover field into adjacent maize field; particularly $C$. undecimpunctata and $S$. interruptus followed by $C$. carnea, Orius spp., $P$. alferii and true spiders.

Table (8): Number of beneficial insect species and their percentages to the total catch on cowpea crop during the two seasons of study.

\begin{tabular}{|c|c|c|c|c|}
\hline \multirow{2}{*}{$\begin{array}{c}\text { Years } \\
\text { Species }\end{array}$} & $\begin{array}{c}|c| \\
\text { Total number } \\
\text { of insect } \\
\text { species }\end{array}$ & $\begin{array}{c}\text { 2010 to the total } \\
\text { numbers }\end{array}$ & $\begin{array}{c}\text { Total number } \\
\text { of insect } \\
\text { species }\end{array}$ & $\begin{array}{c}\text { \% to the total } \\
\text { numbers }\end{array}$ \\
\hline A: Coleoptera & \multicolumn{5}{|l|}{} \\
\hline C. undecimpunctata & 78 & 16.88 & 92 & 23.96 \\
\hline Cy. vicina isis & 33 & 7.14 & 22 & 5.73 \\
\hline Cy. vicina nilotica & 19 & 4.11 & 14 & 3.65 \\
\hline B: Diptera & \multicolumn{5}{|l}{} \\
\hline M. corollae (F.) & 15 & 3.25 & 11 & 2.86 \\
\hline C: Hymenoptera & 300 & 64.94 & 233 & 60.68 \\
\hline L. fabrum & 17 & 3.68 & 12 & 3.13 \\
\hline D: Neuroptera & 462 & 100 & 384 & 100 \\
\hline C. carnea & \multicolumn{5}{|l}{} \\
\hline Total &
\end{tabular}

Table (9): Number of beneficial insect species and their percentages to the total catch on maize plants during the two seasons of study.

\begin{tabular}{|c|c|c|c|c|}
\hline \multirow{2}{*}{$\begin{array}{c}\text { Years } \\
\text { Species }\end{array}$} & $\begin{array}{c}|c| \\
\text { Total number } \\
\text { of insect } \\
\text { species }\end{array}$ & $\begin{array}{c}\text { \% to the total } \\
\text { numbers }\end{array}$ & $\begin{array}{c}\text { Total number } \\
\text { of insect } \\
\text { species }\end{array}$ & $\begin{array}{c}\text { \% to the total } \\
\text { numbers }\end{array}$ \\
\hline A: Coleoptera & \multicolumn{5}{|l|}{} \\
\hline C. undecimpunctata & 15 & 12.82 & 18 & 12.08 \\
\hline B: Diptera & \multicolumn{5}{|l}{} \\
\hline M. corollae (F.) & 13 & 11.11 & 17 & 11.41 \\
\hline D: Neuroptera & \multicolumn{5}{|l|}{} \\
\hline C. carnea & 15 & 12.82 & 19 & 12.75 \\
\hline D: & 19 & 16.24 & 24 & 16.11 \\
\hline E; True spiders & \multicolumn{5}{|l|}{} \\
\hline C: Hymenoptera & 35 & 29.92 & 55 & 36.91 \\
\hline D. rapae & 20 & 17.09 & 16 & 10.74 \\
\hline Praon sp. & 117 & 100 & 149 & 100 \\
\hline Total & \multicolumn{5}{|l|}{}
\end{tabular}

\section{REFERENCES}

Abdel- Samad, S. S. M. (1996) Studies on natural enemies of certain insects attacking leguminous crops. M.S.C. Thesis, Faculty of Agriculture, Ain Shams Univ., 94pp. 
Abd - Elsamed, A.A. (2006) Studies on some homopterous insect vectors of plant diseases .Ph.D. Thesis, Fac. Agric. Zagazig Univ. Egypt. 387 pp

AL-Hag, E.; A.A. AL- Rokaibah and A.A. Zaitoon (1996): Natural enemies of cereal aphids in sprinkler - irrigated wheat in central Saudi Arabia Bulletin of the Fac. of Agric., Cairo university 47:649 - 633.

Ammar, E.D. and S.M. Farrag (1976) Preliminary survey and relative abundance of leafhoppers and planthoppers at Giza using modified light trap. Bull. Soc. Ent. Egypt $60: 297$ - 303.

Costat, S. (1990) Microcomputer program analysis, version 4-20 Cohort Software,Berkly CA,USA.

Darwish, Y.A. and A.M. Ali (1991) Field population trends of cereal aphids and their natural enemies on corn plants in Upper Egypt. Assiut $\mathrm{J}$. Agric. Sci., 22(2): $33-42$.

El- Gindy, M.A. (2002) Studies on certain homopterous insect vectors of plant pathogenic diseases Ph. D. Thesis, Fac. Of Agric., Zagazig Univ. 274pp.

El- Gindy, M.A. (2006) susceptibility of three maize cultivars to leafhopper infestation and effect of potassium fertilization on leafhoppers. Egypt. J. of Appl. Sci., 21(10a): $302-314$.

El- Gindy, M. A.; R.M. El- Refaey and E.E. Hatab (2009) Abundance of some potato homopterous pests as affects by potassium fertilization level. Egypt. Acad. J. Biology Sc., 2(2): 179 - 185.

El-Sayed, A. M. (1993) Insect pests and their associated natural enemies on cowpea (Vigna unguiculata L.) plants. Zagazig J. Agric. Res. 20 : (3) 1175-1183.

Ezuech, M.F. and A. T. Taylor (1984) Effect of time of intercropping with maize on cowpea susceptibility to three major pests. Trop. Agric. (Trinidad) Vol. 61: $47-57$.

Farrell, J.A. and M.W. Stufkens (1990) The impact of Aphidius rhopalosiphi (Metopolophium dirhodum) (Homoptera: Aphididae) on cereals in Cankrbury, Newzeland Bull. Ent. Res., 80 : $377-383$.

Giustina, W.; P. Deriu and P. Foessel (1982) Role of specific natural enemies in the control of maize aphid populations in the Paris area Preliminary results. Bulletin Srop., 10(1): $12-22$.

Hammad, S.M. (1978) Pests of grain legumes and their control in Egypt. Pests of grain legumes Ecological and control. P. 453

Hashem, M.S. (2005) Studies on certain piercing - sucking insects infesting some vegetable crops. Ph.D.Thesis, Fac. Agric. Moshtohr, Zagazige Univ.

Hassan, S. (2009): Effect of variety and intercropping on two major cowpea (Vigna unguiculata(L.) Walip) field pests in Mubi, Adamawa State, Nigeria. J. of Horticulture and Forestry Vol.1(2): 14 - 16.

Hegab , A.M.; I. M. kelany and M. M.,El - Maghraby (1987) Survey of leafhoppers and planthoppers infesting maize plants by using three techniques in newly reclaimed sandy areas at Salhia distric , Egypt. Minia, J. Agric. Rec. \& Dev. 9(2):945- 953.

Hegab-Ola, I.M.S. (1997) Studies on certain homopterous insects vector of plant pathogenic diseases. M. Sc. Thesis, Fac. Agric. Zagazig Univ. 
Hegab-Ola, I.M.S.(2001) Studies on certain insect vectors of plant pathogenic agents. Ph.D. of Science. Fac. Agric. Zagazig Univ.

Hegab, S.A.S. (1993): Studies on certain pest infesting some cruciferous plant. M. Sc. Thesis, Fac. Agric. Zagazig Univ.

Mali, V.R. and K.S. Kulthe (1980) A seed borne potyvirus causing mosaic of cowpea in India. Plant Disease 64: 925 - 928.

Matteson, P.C. (1982) The effects of intercropping with cereal and minimal Permethrin application on insect pests of cowpea and their natural enemies in Nigeria. Tropical Pest Management 28:373-380.

Mohammed, N.E. (1996) Studies on using certain native predators in the control of certain insect pests. M. Sci. Thesis, Fac. of Agric. Mansoura Univ. pp.153.

Mowafy, K.H.A. (1988) Studies on insect pests attacking leguminous field crops in Egypt. Ph. D. Thesis, Fac. of Agric. Moshtohor, Zagazig Univ.

Okigbo, B.N. and D. J. Greenland (1976) Intercropping systems in Tropical Africa American Society of Agronomy. Madison, WI.

Omar, H.I.H.; M.F. Hagdar and A.E.M. El- Sorady (1994): Effect of sowing date of intercropping cowpea with cotton on infestation with some major pests. J. Agric. Rec., 72(3): $691-697$.

Omar, H. I. H.; A. Hegab; H. A. Awad and A. E. M. El- Sorady (1991) Effect of intercropping of cowpea with cotton plants on infestation with some important insect pests. Alex. Sci. Exch. Vol. 12(4): $701-711$.

Perfect, T.J.; A.G. Cook and B.R. Critchley (1978) Effects of intercropping on pest incidence in Ibadan, Nigeria IITA. Memo.

Ragab, M.E.; A.M. Abou El- Naga; A.A. Ghanim and A.A. Saleh (2002) Ecological and biological study on certain aphid parasitoids especially those of Aphis craccivora Koch. J. Agric, Sci. Mansoura Univ., 27(4): 2611-2620.

Ragab, M.E. (1996) Biology and efficiency of Trioxys angelicae Hal. (Hymenoptera: Aphidiidae) anewly recorded parasitoid of Aphis craccivora Koch. (Homoptera : Aphidiidae). Egyptian J. of Biol. Control, 6(1): 7- 11.

Rao, M.S. and K.D. Reedy (1999) Non pesticidal approaches in cotton IPM. a review. Agricultural review (Krnal), 20 (3/4):203-219. (c.f. R.A.E., 88 (11):1399).

Root, R.B. (1973) Organization of a plant arthropod association in simple and diverse habitats, the fauna of collards (Brassica clearces). Ecological Monographs 43:95-124.

Rosseto, D.; J.L. Florcovski and M.H. Calaflori (1997) Influence of fertilizer on Tetranychus urticae and Aphis gossypii infestation on cotton plants. Ecossistema, 22:52-58(c.f. R.A.E., 87(5):639).

Saleh, A. A. (2004): Mass production field application of some aphid natural enemies. Ph. D. Thesis, Fac., of Agric., Mansoura Unvi., 161 PP.

Selim, A.A.; S.A. El-Refai and A., El. Gantiry (1987) Saesonal fluctuations in the population of Aphis craccivora Koch , Myzus persicae (Sulz.) Aphis gossypii (Golv.) and their parasites. Ann. Agric. Sci, Ain Shams Univ., 32(3):1837 - 1848. 
Shoeb, M.A.; A.A. Attalla and A.H. EL- Heneidy (2008) On the migration of common predatory species from Egyptian clover to adjacent maize field in Egypt. Egyptian J. of Biol. Pest Control, 18(2): 385-389.

Singh S.R. and K.O. Rachie (1985) Cowpea research, Production and Utilization. Wiley, London, $448 \mathrm{pp}$.

Tahvanainen, J.O. and R.B. Root (1972) The influence of vegetation diversity on the population ecology of a specialized herbivore, Phyllotreta crucfera (Coleoptera: Chrysomelidae). Oecologia (Berlin) 50: 621 346.

Vaz, L. A. L.; M. T. Travares and C. Lomonaco (2004) Diversity and size of parasitic Hymenoptera of Brevicorne brassicae L. and Aphis nerii Boyer de Fonscolombe (Hemiptera : Aphididae) Neotropical Entomol. Voll. 33(2): $225-230$.

Watson, T.F.; J.C. Silvertooth and A. Tellez (1994) Varietal and nitrogen levels effects on sweet potato whitefly population in cotton. Proceeding of Beltwide Conferences, San Diego, January 5-8, CA, U.S.A.: 868869.

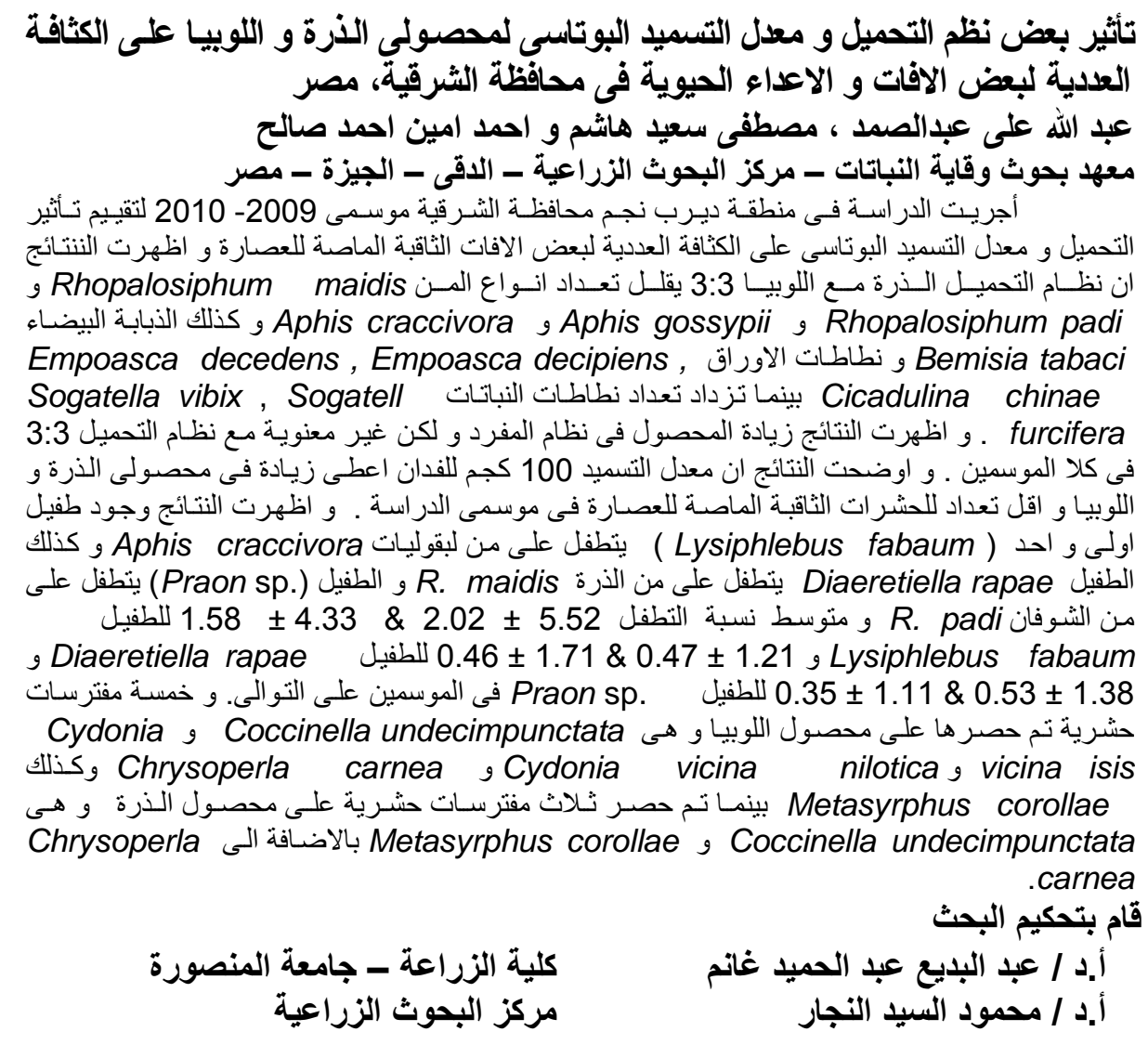


Abd-Elsamed, A.A. et al. 
Table (1): Effect of different intercropping on the infestation of maize plants by certain leaf insects along with yield during 2009 and 2010 seasons.

\begin{tabular}{|c|c|c|c|c|c|c|c|c|c|c|c|c|c|c|c|c|c|c|}
\hline \multirow{3}{*}{ 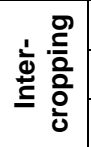 } & \multicolumn{6}{|c|}{ Aphid / sample } & \multicolumn{6}{|c|}{ Leafhopper /sample } & \multicolumn{4}{|c|}{ Planthopper / sample } & \multirow{2}{*}{\multicolumn{2}{|c|}{$\begin{array}{l}\text { Mean yield } \\
\text { kg/plot }\end{array}$}} \\
\hline & \multicolumn{2}{|c|}{ R. maidis } & \multicolumn{2}{|c|}{ R. padi } & \multicolumn{2}{|c|}{ A. gossypii } & \multicolumn{2}{|c|}{ E. decedens } & \multicolumn{2}{|c|}{ E. decipens } & \multicolumn{2}{|c|}{ C. chinae } & \multicolumn{2}{|c|}{ S. vibix } & \multicolumn{2}{|c|}{ S. furcifera } & & \\
\hline & 2009 & 2010 & 2009 & 2010 & 2009 & 2010 & 2009 & 2010 & 2009 & 2010 & 2009 & 2010 & 2009 & 2010 & 2009 & 2010 & 2009 & 2010 \\
\hline solid & $1583.50^{\mathrm{a}}$ & $999.01^{\mathrm{a}}$ & $694.97^{2}$ & $608.27^{\circ}$ & $88.23^{a}$ & $73.53^{a}$ & $63.71^{\mathrm{a}}$ & $46.15^{a}$ & $50.79^{a}$ & $53.14^{a}$ & $43.27^{\mathrm{a}}$ & $36.35^{\mathrm{a}}$ & $36.11^{b}$ & $30.32^{a}$ & $28.52^{a}$ & $31.45^{\mathrm{a}}$ & $39.45^{\mathrm{a}}$ & $49.22^{a}$ \\
\hline $1: 1$ & $928.76^{b}$ & $550.14^{b}$ & $443.68^{b}$ & $331.81^{b}$ & $64.05^{\mathrm{b}}$ & $61.56^{b}$ & $43.82^{b}$ & $38.61^{b}$ & $40.87^{b}$ & $48.46^{\mathrm{b}}$ & $35.58^{\mathrm{b}}$ & $25.21^{b}$ & $37.55^{\mathrm{b}}$ & $34.96^{a}$ & $30.0^{\mathrm{a}}$ & $32.22^{b}$ & $24.62^{b}$ & $30.64^{b}$ \\
\hline $3: 3$ & $840.89^{c}$ & $503.67^{\circ}$ & $391.93^{c}$ & $302.51^{b}$ & $62.82^{\mathrm{b}}$ & $61.95^{b}$ & $37.57^{\mathrm{c}}$ & $38.08^{b}$ & $38.46^{b}$ & $45.68^{b}$ & $33.66^{c}$ & $23.79^{b}$ & $43.82^{a}$ & $40.74^{a}$ & $36.57^{\mathrm{a}}$ & $39.66^{\mathrm{b}}$ & $34.21^{a}$ & $42.79^{a}$ \\
\hline LSD & ** & ** & ** & ** & ** & ** & ** & ** & ** & . & ** & ** & ** & n.s & n.s & ** & ** & ** \\
\hline $0.05 \%$ & 17.828 & 9.863 & 15.82 & 34.54 & 3.902 & 5.586 & 1.415 & 1.424 & 3.414 & 4.173 & 1.516 & 2.869 & 3.495 & & & 1.114 & 5.651 & 7.276 \\
\hline
\end{tabular}

Table (2): Effect of different intercropping on the infestation of cowpea plants by certain leaf insects along with yield during 2009 and 2010 seasons.

\begin{tabular}{|c|c|c|c|c|c|c|c|c|c|c|c|c|c|c|c|c|}
\hline \multirow{3}{*}{ 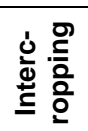 } & \multicolumn{4}{|c|}{ Aphid / sample } & \multicolumn{6}{|c|}{ Leafhopper/ sample } & \multicolumn{4}{|c|}{ Whitefly B. tabaci/sample } & \multirow{2}{*}{\multicolumn{2}{|c|}{$\begin{array}{l}\text { Mean yield } \\
\mathrm{kg} / \mathrm{plot}\end{array}$}} \\
\hline & \multicolumn{2}{|c|}{ Aphis craccivora } & \multicolumn{2}{|c|}{ Aphis gossypii } & \multicolumn{2}{|c|}{ E. decedens } & \multicolumn{2}{|c|}{ E. decipiens } & \multicolumn{2}{|c|}{ C. chinae } & \multicolumn{2}{|c|}{ Adult stage } & \multicolumn{2}{|c|}{$\begin{array}{c}\text { Immature } \\
\text { stage }\end{array}$} & & \\
\hline & 2009 & 2010 & 2009 & 2010 & 2009 & 2010 & 2009 & 2010 & 2009 & 2010 & 2009 & 2010 & 2009 & 2010 & 2009 & 2010 \\
\hline solid & $370.14^{\mathrm{a}}$ & $214.63^{\mathrm{a}}$ & $46.48^{\mathrm{a}}$ & $31.51^{\mathrm{a}}$ & $13.35^{\mathrm{a}}$ & $11.33^{\mathrm{a}}$ & 20. & & & 6.32 & & & & 90. & & $20^{2}$ \\
\hline $1: 1$ & $361.86^{b}$ & $198.44^{b}$ & $37.03^{6}$ & $29.76^{\mathrm{a}}$ & $11.42^{b}$ & $10.43^{b}$ & $17.65^{b}$ & $13.28^{b}$ & $5.57^{\mathrm{a}}$ & $6.18^{\mathrm{a}}$ & $50.60^{b}$ & $31.80^{\mathrm{b}}$ & $99.00^{\mathrm{a}}$ & $81.17^{\mathrm{a}}$ & $6.76 \mathrm{~b}$ & $7.60^{b}$ \\
\hline $3: 3$ & $263.68^{\mathrm{c}}$ & $185.81^{\mathrm{C}}$ & $27.83^{\mathrm{C}}$ & $22.20^{b}$ & $11.17^{\circ}$ & $9.88^{b}$ & $16.13^{\mathrm{C}}$ & $13.08^{b}$ & $5.53^{\mathrm{a}}$ & $5.90^{\mathrm{a}}$ & $34.17^{c}$ & $28.72^{\mathrm{C}}$ & 80.00 & $73.43^{\mathrm{a}}$ & $8.05 a$ & $9.78^{\mathrm{a}}$ \\
\hline LSD & $\star *$ & $* *$ & $\star *$ & $\star *$ & ** & $\star *$ & ** & $\star *$ & n.s & n.s & $\star *$ & 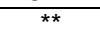 & n.s. & n.s. & $* *$ & $* *$ \\
\hline $0.05 \%$ & 3.661 & 2.198 & 1.463 & 2.329 & 0.263 & 0.630 & 0.682 & 0.872 & & & 2.262 & 0.730 & & & 1.061 & 1.154 \\
\hline
\end{tabular}

Means followed by the same letter in a column between the three intercropping systems are not significantly different at the (L.S.D.5\%)

level of probability 
Table (3): Effect of different levels potassium fertilization on the infestation of maize plants intercropping with cowpea plants by certain leaf insects along with yield during 2009 and 2010 seasons.

\begin{tabular}{|c|c|c|c|c|c|c|c|c|c|c|c|c|c|c|c|c|c|c|}
\hline \multirow{3}{*}{ 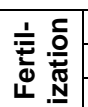 } & \multicolumn{6}{|c|}{ Aphid insects } & \multicolumn{6}{|c|}{ Leafhopper insects } & \multicolumn{4}{|c|}{ Planthopper insects } & \multirow{2}{*}{\multicolumn{2}{|c|}{$\begin{array}{c}\text { Mean yield } \\
\text { kg/plot }\end{array}$}} \\
\hline & \multicolumn{2}{|c|}{ R. maidis } & \multicolumn{2}{|c|}{ R. padi } & \multicolumn{2}{|c|}{ A. gossypii } & \multicolumn{2}{|c|}{ E. decedens } & \multicolumn{2}{|c|}{ E. decipens } & \multicolumn{2}{|c|}{ C. chinae } & \multicolumn{2}{|c|}{ S. vibix } & \multicolumn{2}{|c|}{ S. furcifera } & & \\
\hline & 2009 & & 2009 & 20010 & & & 2009 & & & & & & & & & & & \\
\hline F1 & $955.99^{\mathrm{a}}$ & $596.26^{a}$ & $418.27^{\mathrm{a}}$ & $324.96^{\mathrm{a}}$ & $59.41^{\mathrm{a}}$ & $55.57^{\mathrm{a}}$ & $33.06^{\mathrm{a}}$ & $33.31^{\mathrm{a}}$ & $38.16^{\mathrm{a}}$ & $43.84^{\mathrm{a}}$ & $32.03^{\mathrm{a}}$ & $22.11^{\mathrm{a}}$ & $35.48^{\mathrm{a}}$ & $9.20^{\mathrm{a}}$ & $26.74^{\mathrm{a}}$ & $28.71^{\mathrm{a}}$ & $46.36^{\mathrm{a}}$ & $3.03^{\mathrm{a}}$ \\
\hline F2 & & & & & & & 37.5 & 37.0 & & & $35.20^{b}$ & & $36.39^{\mathrm{a}}$ & & & & & \\
\hline F3 & & & 543 & & & 68. & 41 & $44.35^{\circ}$ & & & $.98^{\circ}$ & & $40.96^{b}$ & & & & & \\
\hline F4 & $272.28^{\mathrm{a}}$ & $782.76^{\mathrm{d}}$ & $597.87^{\circ}$ & $494.97^{\circ}$ & $83.54^{\mathrm{d}}$ & $74.93^{\mathrm{C}}$ & $45.14^{\mathrm{d}}$ & $49.12^{\mathrm{d}}$ & $48.75^{\mathrm{c}}$ & $54.32^{b}$ & $42.79^{\mathrm{d}}$ & $34.26^{c}$ & $43.81^{b}$ & $40.89^{b}$ & $36.96^{\mathrm{C}}$ & $41.46^{\mathrm{a}}$ & $16.56^{\mathrm{d}}$ & 20.4 \\
\hline LSD & & 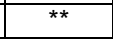 & ** & ** & & 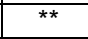 & $*$ & & & ** & $* *$ & $*$ & & & & & & \\
\hline $.05 \%$ & 9.560 & 10.921 & 17.59 & 15.51 & 2.861 & 4.317 & 1.167 & 2.606 & 3.008 & 2.886 & 2.288 & 2.848 & 3.04 & 4.967 & 4.174 & 1.968 & 4.126 & 5.097 \\
\hline
\end{tabular}

Table (4): Effect of different levels potassium fertilization on the infestation of cowpea plants by certain leaf insects along with yield during 2009 and 2010 seasons.

\begin{tabular}{|c|c|c|c|c|c|c|c|c|c|c|c|c|c|c|c|c|}
\hline \multirow{3}{*}{ 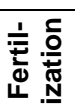 } & \multicolumn{4}{|c|}{ Aphid } & \multicolumn{6}{|c|}{ Leafhopper } & \multicolumn{4}{|c|}{ whitefly } & \multirow{2}{*}{\multicolumn{2}{|c|}{$\begin{array}{l}\text { Mean yield } \\
\text { kg/plot }\end{array}$}} \\
\hline & \multicolumn{2}{|c|}{ Aphis craccivora } & \multicolumn{2}{|c|}{ Aphis gossypii } & \multicolumn{2}{|c|}{ E. decedens } & \multicolumn{2}{|c|}{ E. decipiens } & \multicolumn{2}{|c|}{ C. chinae } & \multicolumn{2}{|c|}{ Adult stage } & \multicolumn{2}{|c|}{ Immature stage } & & \\
\hline & 2009 & 20010 & 2009 & 20010 & 2009 & 20010 & 2009 & 20010 & 2009 & 20010 & 2009 & 20010 & 2009 & 20010 & 2009 & 20010 \\
\hline $\mathrm{F} 1$ & $295.36^{a}$ & $174.58^{\mathrm{a}}$ & $27.33^{\mathrm{a}}$ & $21.33^{\mathrm{a}}$ & $8.87^{\mathrm{a}}$ & $8.26^{\mathrm{a}}$ & $11.79^{\mathrm{a}}$ & $10.30^{\mathrm{a}}$ & $4.70^{\mathrm{a}}$ & $4.91^{\mathrm{a}}$ & $38.04^{\mathrm{a}}$ & $26.14^{\mathrm{a}}$ & $72.24^{\mathrm{a}}$ & $74.65^{\mathrm{a}}$ & $10.70^{\mathrm{a}}$ & 13.02 \\
\hline $\mathrm{F} 2$ & $322.32^{b}$ & $192.81^{b}$ & $34.94^{b}$ & $25.31^{b}$ & $11.37^{b}$ & $9.82^{b}$ & $15.23^{b}$ & $12.82^{b}$ & $5.28^{b}$ & $5.91^{b}$ & $47.58^{\mathrm{b}}$ & $30.60^{b}$ & $90.403^{b}$ & $86.73^{b}$ & $8.14^{b}$ & $9.14^{b}$ \\
\hline F3 & $346.39^{c}$ & $204.96^{c}$ & $39.66^{c}$ & $29.76^{c}$ & $12.97^{c}$ & $11.32^{c}$ & $19.92^{c}$ & $15.64^{\mathrm{C}}$ & $5.94^{\mathrm{C}}$ & $6.53^{\mathrm{c}}$ & $57.68^{c}$ & $34.14^{c}$ & $94.736^{\mathrm{c}}$ & $89.81^{\mathrm{c}}$ & $7.06^{\mathrm{bc}}$ & $7.93^{\mathrm{bc}}$ \\
\hline $\mathrm{F} 4$ & $363.50^{d}$ & $226.15 d$ & $46.52^{\mathrm{d}}$ & $34.89^{d}$ & $14.71^{\mathrm{d}}$ & $12.79^{\mathrm{d}}$ & $25.92^{\mathrm{d}}$ & $18.46^{\mathrm{d}}$ & $6.62^{\mathrm{d}}$ & $7.21^{\mathrm{d}}$ & $66.20^{\mathrm{d}}$ & $36.93^{\mathrm{d}}$ & $105.22^{\mathrm{d}}$ & $118.6^{\mathrm{d}}$ & $5.96^{\mathrm{C}}$ & $6.67^{\circ}$ \\
\hline LSD & $\star *$ & $\star *$ & $* *$ & ** & $\star *$ & $* *$ & $* *$ & $\star \star *$ & $* *$ & 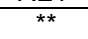 & $* *$ & $* *$ & $\star *$ & . & 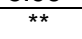 & 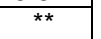 \\
\hline $.05 \%$ & 3.077 & 10.69 & 1.588 & 1.149 & 0.760 & 0.463 & 0.474 & 0.891 & 0.239 & 0.236 & 1.283 & 1.382 & 174.75 & 416.14 & 1.315 & 7 \\
\hline
\end{tabular}

$F_{1}=100 \mathrm{~kg}$ of potassium fertilization $/$ fed. $\quad F_{2}=50 \mathrm{~kg}$ of potassium fertilization $/$ fed. $\quad F_{3}=25 \mathrm{~kg}$ of potassium fertilization $/ \mathrm{fed}$.

$\mathrm{F}_{4}=$ Control (without potassium fertilization)

Means followed by the same letter in a column between the four levels potassium fertilization are not significantly different at the (L.S.D.5\%) level of probability. 